\title{
NUMBER 3
}

\section{NOVEMBER 2018}

British Journal of
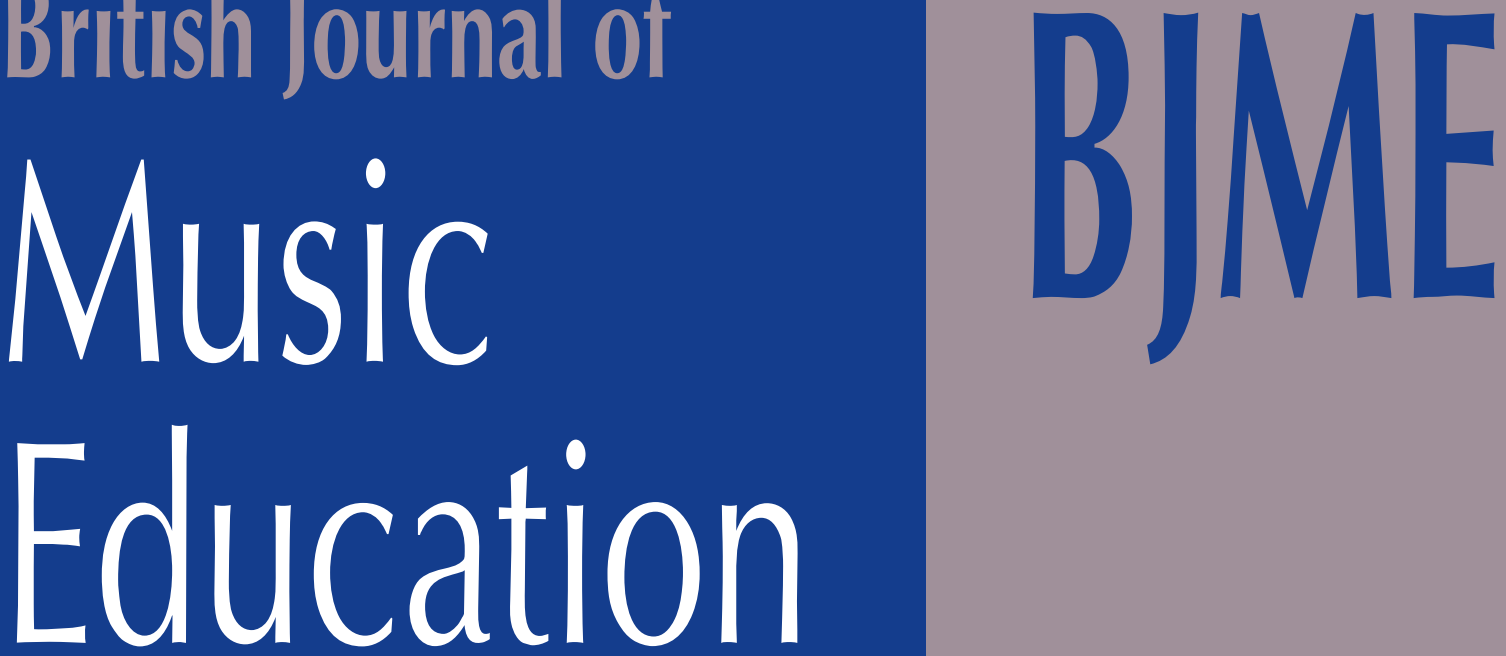

An International Journal 


\section{BRITISH JOURNAL OF MUSIC EDUCATION}

\section{Editor}

MARTIN FAUTLEY Birmingham City University, UK

ALLY DAUBNEY University of Sussex, UK

\section{Book Review Editor}

KAREN BURLAND University of Leeds, UK

\section{Journal Administrator}

CORMAC LAMBE Dublin City University, Ireland

\section{Editorial Board}

\section{ANTHONY ANDERSON}

Birmingham City University, UK

JAMES BIDDULPH

London, UK

TIM CAIN

University of Southampton, UK

MARTIN CLOONAN

University of Glasgow, UK

GARETH DYLAN SMITH

Institute of Contemporary Music Performance, UK

JOHN FINNEY

University of Cambridge, UK

MARINA GALL

University of Bristol, UK

HELENA GAUNT

Guildhall School of Music \& Drama, UK

LUCY GREEN

University of London, UK

DIANA HARRIS

Open University, UK

JENNIE HENLEY

Royal College of Music, UK

KATHRYN JOURDAN

St Mary's Music School, Edinburgh, UK

DEBORAH MAWER

Birmingham Conservatoire, UK

GWEN MOORE

Mary Immaculate College - University of Limerick, Ireland

TIA DE NORA

University of Exeter, UK

OSCAR ODENA

School of Education, University of Glasgow, UK

JESSICA PITT

University of Roehampton, UK

JONATHAN SAVAGE

Manchester Metropolitan University, UK

IAN SHIRLEY

Edge Hill University, UK

HUGH SMITH

University of the West of Scotland, UK

GRAHAM WELCH

University of London, UK

VANESSA YOUNG

Canterbury Christ Church University, UK

SALLY-ANNE ZIMMERMANN

Royal National Institute for the Blind (RNIB), UK

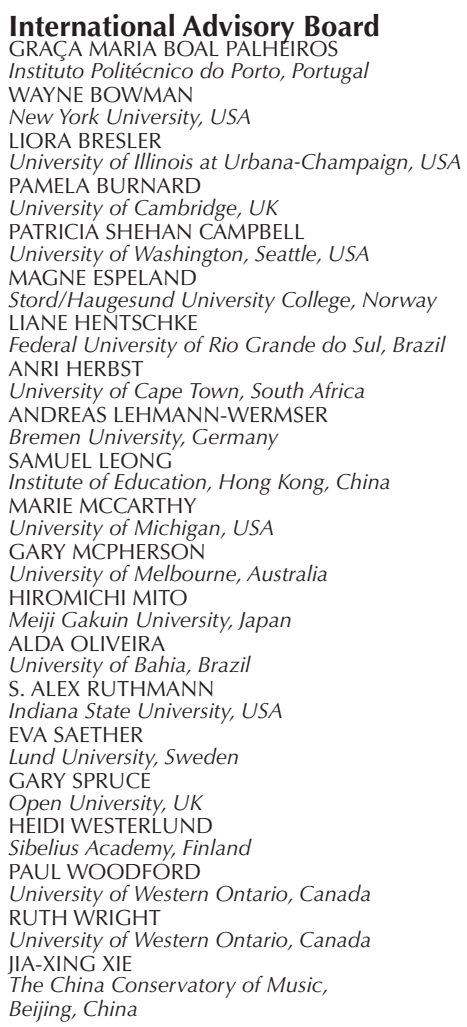

The British Journal of Music Education (ISSN 0265-0517) is a fully refereed international journal which aims to present clear and stimulating research on all aspects of music education. It is published in volumes of three parts in March, July and November.

Subscriptions: The subscription price which includes postage plus electronic access to institutional subscribers (excluding VAT) of volume 35, 2018 is $£ 255$ (US \$437 in USA, Canada and Mexico) and $£ 32$ (US \$52 in USA, Canada and Mexico) for students ordering direct from the Press and certifying that the journal is for their personal use. Single parts cost $£ 98$ net (US \$168 in USA, Canada and Mexico) plus postage. An electronic only price is available to institutional subscribers at $£ 219$ (US \$373 in USA, Canada and Mexico). EU subscribers (outside the UK) who are not registered for VAT should add VAT at their country's rate. VAT registered subscribers should provide their VAT registration number. Orders, which must be accompanied by payment, may be sent to a bookseller, subscription agent or direct to the publishers: Cambridge University Press, Journals Fulfilment Department, UPH, Shaftesbury Road, Cambridge CB2 8BS, UK. Orders from the USA, Canada or Mexico should be sent to Cambridge University Press, Journals Fulfillment Department, 1 Liberty Plaza, Floor 20, New York, NY 10006, USA. Periodicals postage paid at New York, NY, and at additional mailing offices. Prices include delivery by air. Japanese prices for institutions are available from Kinokuniya Company Ltd, PO Box 55, Chitose, Tokyo 156, Japan.

Copying: This journal is registered with the Copyright Clearance Center, 222 Rosewood Drive, Danvers, MA 01923. Organizations in the USA who are also registered with CCC may therefore copy material (beyond the limits permitted by sections 107 and 108 of US copyright law) subject to payment to CCC

Organizations authorized by the Copyright Licensing Agency may also copy material subject to the usual conditions. ISI Tear Sheet Service, 3501 Market Street, Philadelphia, PA 19104, USA, is authorized to supply single copies of separate articles for private use only. 